\title{
ANALYSIS OF SLOPE STABILIZING PILES
}

\author{
Tarek N. Salem, Mohsen M. A. Mashhour, Rana H. Rashad** \\ Structural Eng. Dept., Zagazig University, Egypt
}

\begin{abstract}
Slope stability is one of the most important problems in geotechnical engineering because failure could cause catastrophic environmental and human disaster, in addition to large economical losses due to such failure. The purpose of this paper is to study the effect of using piles to stabilize the embankments of Al-Salam Canal in Northern Egypt. The canal left side is a formed soft clay embankment. The left side embankment is mainly formed from the dredging and cleaning of the bottom of the nearby Al-Manzala lake. Sudden and progressive failures took place in the left side over years. These failures are mainly due to the nature of the soft clay forming the slope in addition to the existence of gypsum and peat pockets and thin layers within the slope in many locations. Thus, it was suggested to use reinforced concrete piles to stabilize the left side embankment of the canal. Analysis of the slope stabilized by piles is performed using the finite element analysis program $\left(\mathrm{Phase}^{2}\right)$. Although the slope stabilizing piles are able to stabilize the slope, but increasing the number of pile rows was not effective in increasing the safety factor in return. Another slope stabilizing technique is studied herein using lime treatment. The proposed lime treatment was effective in stabilizing the slope more than the slope stabilizing piles, and even in the zones containing the peat layer.
\end{abstract}

KEYWORDS: Slope Stability; Piles; Soft Clay; Peat; Lime Treatment.

\section{ANALYSE DES PILES DE STABILISATION DES TALUS}

\section{RÉSUMÉ}

La stabilité des talus est l'un des problèmes les plus importants en ingénierie géotechnique, car la défaillance pourrait entraîner catastrophique en cas de catastrophe environnementale et humaine, en plus de grandes pertes économiques dues à un tel manquement. Le but de cet article est d'étudier l'effet de l'utilisation de piles à stabiliser les remblais d'Al-Salam Canal dans le nord de l'Egypte. Le côté du canal de gauche est un remblai argileux formé doux. Le remblai côté gauche est principalement formé à partir de dragage et de nettoyage du fond de l'proximité Al-Manzala lac. Défaillances subites et progressive a eu lieu dans le côté gauche au fil des ans. Ces échecs sont principalement dus à la nature de l'argile molle formant la pente, en plus de l'existence de poches de gypse et de la tourbe et de couches minces à l'intérieur de la pente dans de nombreux endroits. Ainsi, il a été suggéré d'utiliser pieux en béton armé pour stabiliser le talus côté gauche du canal. Analyse de la pente stabilisée par des pieux est effectuée en utilisant le programme analyse par éléments finis (Phase2). Bien que la pente de stabilisation des piles sont capables de stabiliser la pente, mais en augmentant le nombre de lignes de pieux n'était pas efficace pour augmenter le facteur de sécurité en retour. Un autre versant de stabilisation technique est étudiée ici en utilisant traitement à la chaux. Le traitement proposé la chaux a été efficace dans la stabilisation de la pente de plus de la pente de stabilisation des piles, et même dans les zones contenant la couche de tourbe.

MOTS-CLES: stabilité des talus; Piles; argile molle; Tourbe; traitement à la chaux.

\footnotetext{
* Received: 7/2/2012, accepted: 7/3/2012 (Original Paper)

** Contact author (roony567@yahoo.com)
} 


\section{INTODUCTION}

Slope stabilizing piles are widely used to stabilize slopes. These piles are mainly subjected to lateral pressure from the horizontal movement caused by the sliding mass. Laterally loaded piles have been studied by many researchers. Formulas to estimate the lateral pressure on laterally loaded piles were introduced by many researchers such as Ito et al. (1975, 1978), Randolph and Houlsby, (1984), Broms, (1964), Poulos and Davis, (1980) and Reese, (1958). Many techniques were proposed in order to analyze slopes stabilized by piles like Rowe and Poulos, (1979), Ito et al., (1981), Viggiani, (1981), Hull, (1993), Poulos, (1995, 1999), Chow, (1996), Bransby and Springman, (1996, 1999), Lee et al., (1995), Hassiotis et al., (1997). Cai and Ugai, (2000) studied the effect of stabilizing piles on the stability of a slope by three-dimensional elasto-plastic shear strength reduction finite element method. Ausilio et al., (2001) presented a kinematic approach for the stability analysis of slopes reinforced with piles. Chen and Martin (2002) examined the existence of an arching zone around landslide stabilizing pile groups for granular and finegrained soils using the finite difference computer program FLAC. Won et al., (2005) studied the coupled effects in stability analysis of pile-slope systems and it was found that the uncoupled analysis which introduced by Jeong et al. (2003) should be limited in its application. Nian et al., (2008) showed that combination of the limit analysis kinematic approach and the strength reduction technique provides a convenient and effective approach for stability analysis of slopes in anisotropic and non-homogeneous slopes. Wei and Cheng, (2009) found that the critical slip surface was found to be divided into two parts when the pile spacing is small, and these two parts gradually get connected with increasing the pile spacing till a clear critical slip surface is formed. The newly formed critical slip surface is similar to that formed in the case of a slope without stabilizing piles.

The studied case is the left side embankment of Al-Salam canal in Northern Egypt. This canal starts at the Nile river estuary from Damietta and transmits the excess Nile water into Sinai Peninsula. The embankment extends for a length of about $89.750 \mathrm{~km}$ from the Damietta branch till reaching the Suez Canal. The embankment was originally a formed one, in which dredged soft clay, organic materials, and gypsum formed pockets and even layers within the slope. It should be noted that the peat layer caused most of the slope failures and the gypsum pockets even caused local failures in the slope accompanied by water piping when the water level in occasions of the nearby Al-Manazala lake is higher than that in Al-Salam Canal.

As a part of the strategic project of developing the Sinai Peninsula, it was decided to widen the canal width, along with improving the capacity and widen the highway in the canal left side.

There is an existing highway in the canal right side, with no apparent stability problems for being a cut slope in a relatively stiffer soil. Widening the first $22 \mathrm{~km}$ of the canal width is performed by cutting $3 \mathrm{~m}$ from the left side berm. So, the canal embankments with this soft soil could not be stable enough to sustain such widening along with the expected highway traffic loads, Al-Ashaal et al., (1998). Field investigations were performed to evaluate the current slope status, and suggest the proposed stabilizing technique including the slope stabilizing piles. Of concern at that time, was the piling construction technique. CFA (continuous flight auger) piles will not assure hindering the caving of the soft soil inside the bored pile. However, hammer driving will induce vibrations that will cause local or general failure in the embankment body. On the one hand, using full displacement pile will compress and improve the soft soil behavior laterally, on the other hand, displacement piles are mainly driven pile. Thus, it was decided to use steel casing in the driving to induce the displacement pile effect, and the driving process is performed using vibratory drivers. Keeping the vibrations lower than the natural frequency of the soil in which the piles are being driven, along with minimizing the driving amplitude have successfully accomplished both tasks. These tasks are employing displacement piles, and prevent caving of the soil in case of using CFA piles.

The embankment stabilization using piles is initially assessed using the simplified Janbu method, followed by another assessment using the wedge method. Both solution techniques 
using two slope stabilizing pile rows led to safety factors of more than 1.50 , satisfying the requirements of the Egyptian Code of Practice for Soil Mechanics and Execution of Foundation for this case. Therefore, in this study the effect of slope stabilizing piles in increasing the safety factor of the embankment is exclusively studied in this research using the finite element software Phase ${ }^{2}$.

\section{STABILIZING AL-SALAM CANAL LEFT SIDE EMBANKMENT}

The general configurations of the left embankment of Al-Salam canal is presented in Fig. (1) and Fig. (2). The figures show the typical left side embankment after widening the canal cross-section and providing adequate slope stabilization technique to allow for the heavy traffic expected over that embankment. The extensive monitoring zones are chosen namely; from 7.700 to $7.750 \mathrm{~km}$ and from 8.800 to $8.850 \mathrm{~km}$. These zones are mainly chosen due to the presence of the peat layer, as assured from the boreholes performed along the whole embankment length.

It should be noted that the full-scale embankment test was performed in the first extensive monitoring zone, Youssef and AlGayar, (2000).

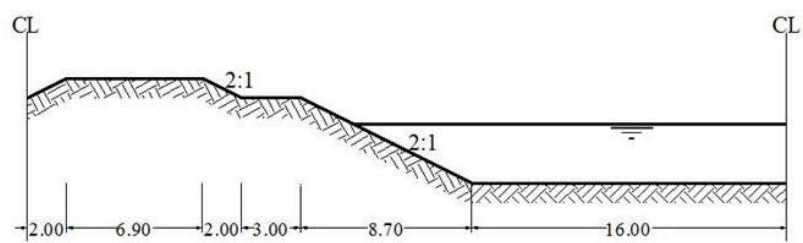

Fig. (1): Schematic Diagram of Al-Salam Canal Cross Section after Widening.

It was suggested to use a slope stabilization system that consists of two rows of reinforced concrete piles, $50 \mathrm{~cm}$ in diameter and $16 \mathrm{~m}$ in length. The pile reinforcement was $12 \square 22$, the distance between two pile rows is 2 $\mathrm{m}$, and the center to center spacing between the piles in a single row is $1.25 \mathrm{~m}$. The second row of piles was constructed in a thin cutoff wall constructed of bentonite slurry and cement to prevent seepage from and into the canal, because of the high salinity of Al-Manzala lake.

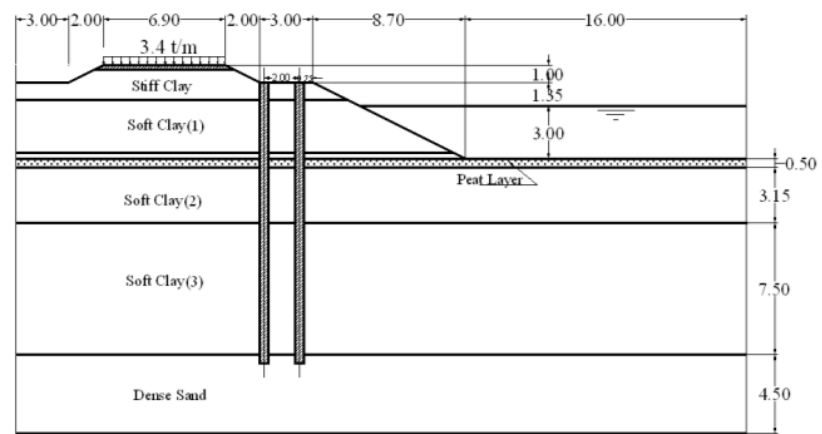

Fig. (2): Slope Profile Showing the Stabilizing System.

The construction technique of the piles was mainly driven cast in situ piles, as previously stated. Connecting beams were cast above the pile heads; moreover, these connecting beams were both laterally connected at a regular spacing of $2.00 \mathrm{~m}$. The connecting beams cross-section was $60 \times 60 \mathrm{~cm}$ and reinforced with $16 \square 16$ in the longitudinal direction. Fig. (3) shows a top view of the stabilizing system elements showing the stabilizing piles, sand drains in order to dissipate the excess pore water pressure generated from piles driving, along with the bentonite slurry seepage cutoff wall.

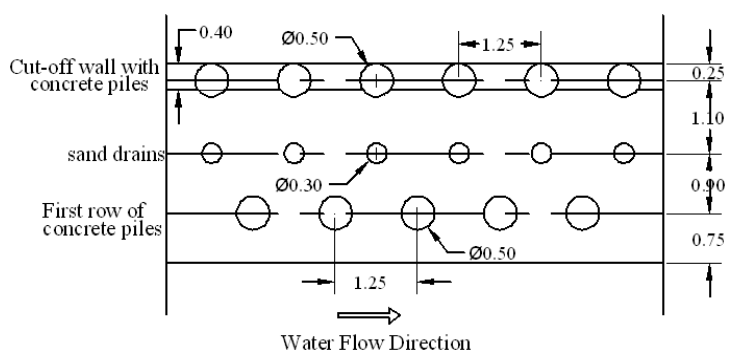

Fig. (3): Top View of the Stabilizing System.

\section{NUMERICAL MODELING OF STABILIZED SLOPE}

The finite element software used in modeling the stabilized slope is $\left(\mathrm{PHASE}^{2}\right.$ ). The software is a 2-dimensional elasto-plastic finite element program for calculating stresses and displacements around underground openings, and can be used to solve a wide range of slope stability and civil engineering problems, (Phase ${ }^{2}, \mathrm{~V} .8$ ). The safety factor is calculated using the Shear Strength Reduction method (SSR). The failure criterion used in the slope analysis was Mohr-Coulomb because the Mohr-Coulomb criterion better represents the soil behavior in addition to the physical meaning of its parameters (Das, 1983; Bishop, 


\section{Salem, Mashhour, Rashad}

1966). The element used in modeling the slope is a 6-nodded triangular element. Peizometric lines are used to model the water level in the program, as shown in Fig. (4), to allow for accurate modeling of the presence of the seepage cutoff wall.

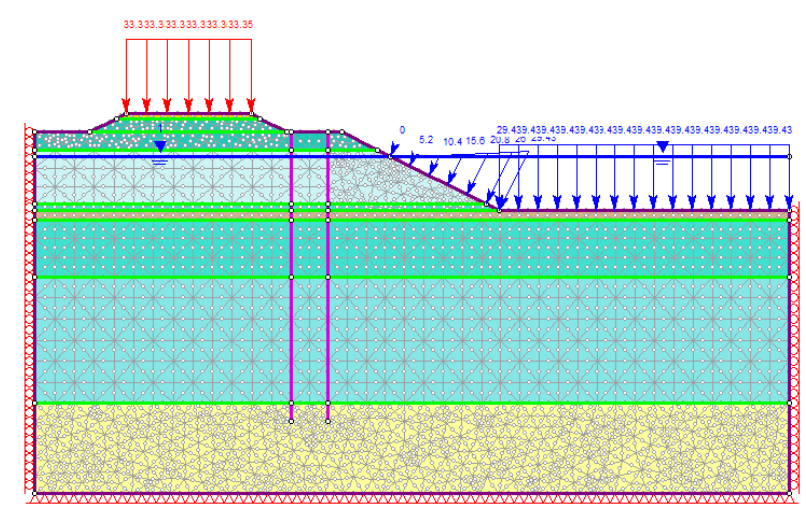

Fig. (4): Finite Element Model of the Stabilized Canal Embankment.
The soil properties used in the slope analysis is correlated from the soil investigation reports, along with the data presented in Al-Ashaal (1998). These properties are presented in Table (1), and Fig. (2) shows the soil stratification used in the analysis of the slope.

Table (3-1): Canal Soil Properties.

\begin{tabular}{|c|c|c|c|c|c|c|}
\hline Soil Type & $\gamma_{\text {sat }}\left(K N / m^{3}\right)$ & E (MPa) & $v$ & c (KPa) & $\phi\left({ }^{\circ}\right)$ & $\psi\left(\left(^{\circ}\right)\right.$ \\
\hline Soft Clay layer(1) & 17 & 1.70 & 0.45 & 16.0 & 5 & 0.0 \\
\hline Soft Clay layer (2) & 16 & $\overline{1.40}$ & 0.45 & 14.0 & 0.0 & 0.0 \\
\hline Soft Clay layer (3) & 17 & 2.00 & 0.45 & 23.0 & 0.0 & 0.0 \\
\hline Stiff Clay layer & 17 & 5.90 & 0.45 & 45.0 & 0.0 & 0.0 \\
\hline Peat layer & 11 & 0.30 & 0.45 & 3.0 & 0.0 & 0.0 \\
\hline Dense sand & 18 & 100.0 & 0.30 & 0.0 & 38 & 8 \\
\hline Gravel layer & 19 & 200.0 & 0.30 & 0.0 & 45 & 15 \\
\hline
\end{tabular}

In which:

$\gamma_{\text {sat }}$ : Saturated unit weight;

E : Soil Young's modulus;

$v:$ Poisson's ratio;

c : Soil cohesion;

$\phi:$ Angle of internal friction; and

$\psi$ : Dilation angle $(\phi-30)$.

\section{ANALYSIS OF RESULTS}

Analysis of the slope showed that the calculated safety factor before using any stabilizing system is found to be (1.037), in which case the slope is in just stable condition, and susceptible to failure at any point, as presented in Fig. (5) without external loading. However, using the proposed stabilizing system increased the calculated safety factor into (1.254), as shown in Fig. (6), for a loaded slope. It should be noted that even after using the proposed slope stabilizing system the calculated safety factor has not satisfied the minimum safety factor required by the Egyptian Code of Practice, (2001). Moreover, using a single row of stabilizing piles instead of the proposed system containing two pile rows resulted in reducing the safety factor of the slope into 1.199 , which comprises only about 5\% reduction in that factor. Economically, almost doubling the cost to gain 5\% increase in the safety factor is not feasible, especially if both conditions did not achieve the code requirements.

The presence of the peat layer underneath such clay slope, at approximately the bed level, presents a pre-existing sliding surface that reduces the safety factor into such low values, as indicated in the horizontal displacement shading contours shown in Fig. (5). Although using the stabilizing system has blocked such type of failure presented in Fig. (5), but in return it allows for forming a new 
failure surface in front of the newly constructed stabilizing pile rows. Previous research indicated that the best position for such stabilizing piles is in the middle height of the embankment, in which the pile rows divide the sliding surface into two parts, Wei et al., (2009). In addition, installing the stabilizing pile rows in such position achieves the target of placing such piles in almost the middle of the peat layer sliding surface. The calculated embankment maximum horizontal displacement was $34.70 \mathrm{~cm}$ before using the proposed stabilizing system at the slope toe, and without even applying the traffic loads. On the other hand, after using the stabilizing system and applying the surface equivalent traffic loads, which equals $33.35 \mathrm{kN} / \mathrm{m}^{2}$, an additional horizontal displacement of 15.15 $\mathrm{cm}$ and $14.30 \mathrm{~cm}$ took place behind and in front the piles, respectively, as shown in Fig. (6). This emphasizes that the piles have actually divided the sliding mass into two zones. The relatively large values of horizontal displacement indicate the weak nature of such soft clay and peat, which resulted in such values under normal traffic loads.

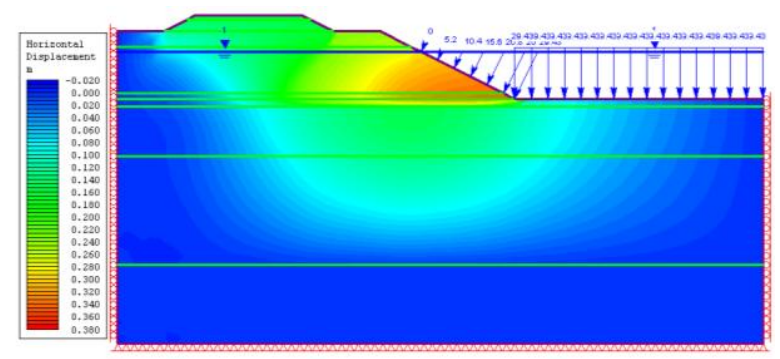

Fig. (5): Horizontal Displacement before Using the Stabilizing System.

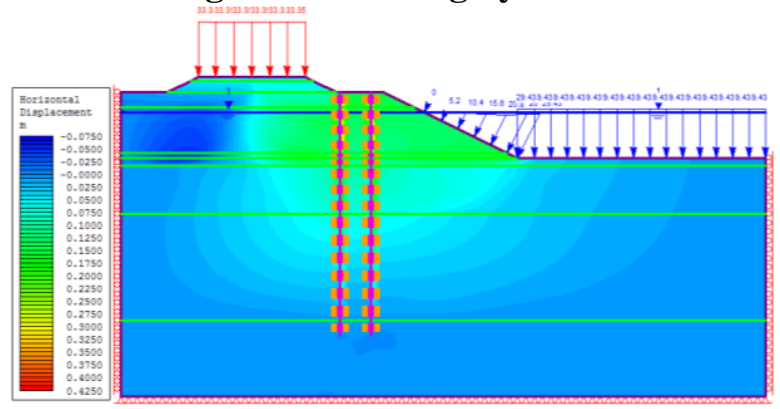

Fig. (6): Horizontal Displacement after Using the Stabilizing System.

The settlement due to the own weight of the embankment only was found to be $24.30 \mathrm{~cm}$ before using the stabilizing piles, as shown in Fig. (7). However, the calculated embankment settlement due to traffic load is found to be $23.40 \mathrm{~cm}$, as presented in Fig. (8). The results from the loading test performed in the extensive monitoring zone showed that the recorded total settlement at the top of the embankment was $18.0 \mathrm{~cm}$, Youssef and Al-Gayar, (2000).

The differences between the calculated and recorded settlement values may be due to the fact that the peat is not actually a layer, but rather a pocket at a portion of the tested embankment. It was mentioned in the embankment loading test report that the settlement values increased in the soft clay layers with the increase of the equivalent load, which in turn will lead to a gradual improvement in the soil properties because of the dissipation of the excess pore water pressure and accelerating the consolidation process.

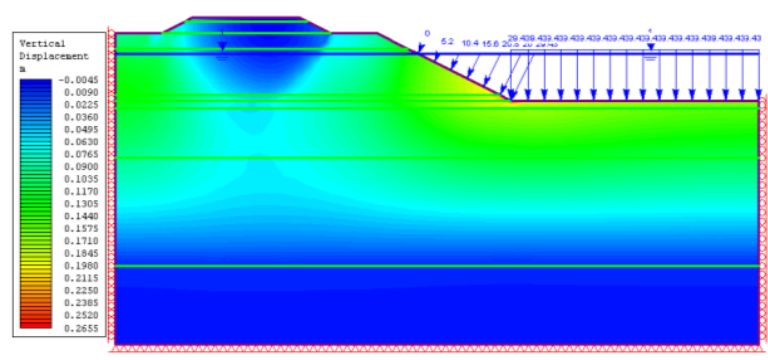

Fig. (7): Settlement Shading Contours Due to the Slope Own Weight.

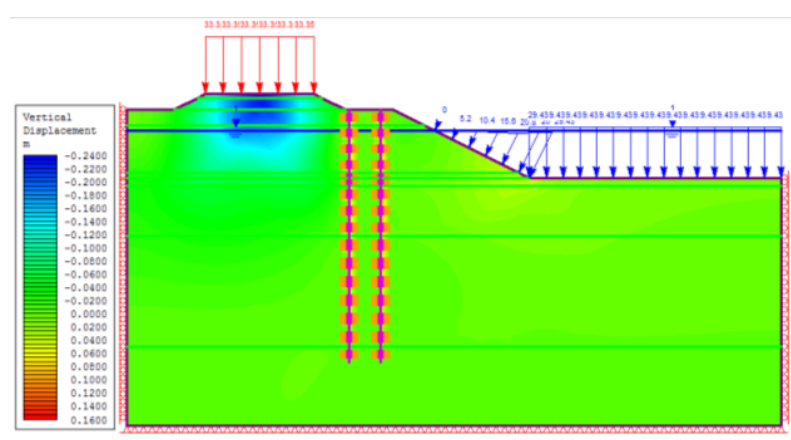

Fig. (8): Settlement Shading Contours of the Stabilized Slope under Equivalent Traffic Loads.

Figs. (9) and (10) show the bending moment and the shear forces developed on the stabilizing pile row due to the lateral soil pressure. The bending moment along the pile length changed its direction in the region of the peat layer as the soil mass under this layer becomes the resisting mass against the slope failure. The pile length extended under the failure surface is about $11 \mathrm{~m}$ and this 
Salem, Mashhour, Rashad

length is sufficient to avoid the piles mobilization by the sliding mass through the stable soil under the sliding surface. The first piles row is the row beside the waterway and the second one at a distance $2.0 \mathrm{~m}$ from the first row. The maximum absolute value of the bending moment on the first piles row is $135.65 \mathrm{kN} . \mathrm{m}$ while for the second row is $128.15 \mathrm{kN}$.m. The maximum shear force is at the piles tip; this may be due to the fixity which caused by driving piles in the lower sand layer till refusal took place. It should be noted that a large increase shear resistance took place when the pile penetrates into the dense sand layer, as presented in Fig. (10).

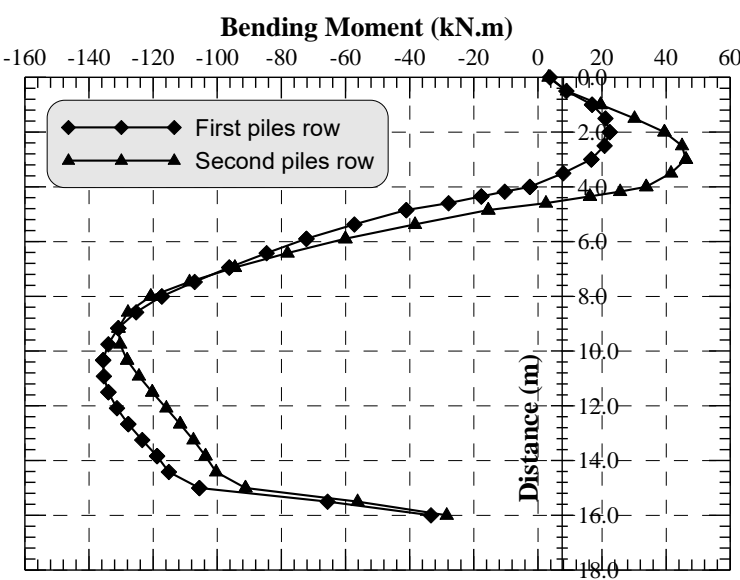

Fig. (9): the bending moment diagram subjected to the piles.

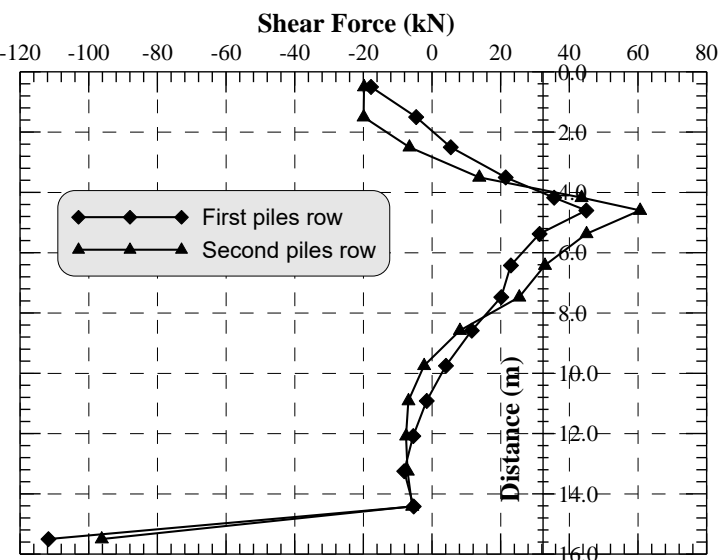

Fig. (10): the shear forces on the piles length.

\section{PARAMETRIC STUDY}

For the sake of completeness the scope of the current paper, a parametric study is performed to highlight the effect of the soil and stabilizing system parameters on the safety factor of the stabilized slope. The modeled embankment is cohesive soil that containing a peat layer and followed by dense sand. Fig. (11) illustrates a schematic diagram for the studied slope geometry and configurations including the followings:

- c: Soil cohesion ranging between 10 and $50\left(\mathrm{kN} / \mathrm{m}^{2}\right)$, with small friction angles $\left(5^{\circ}\right.$ and $\left.10^{\circ}\right)$.

- H: Slope height, varying from 3 to 10 meters;

- $\beta$ : Slope angle, varying from 26.57 to 70 degrees;

- P: Depth of $0.50 \mathrm{~m}$ thick peat layer from the slope crest, varying from 1 to 16 meters;

- N: Number of piles rows, slope studied for one and two piles rows;

- $\mathrm{H}_{\mathrm{w}}$ : Height of water in the canal, varying from 0 to slope height $\mathrm{H}$ $1.00 \mathrm{~m}$;

Other parameters included the presence of the external load; along with the concrete pile properties such as pile length, diameter, and stiffness.

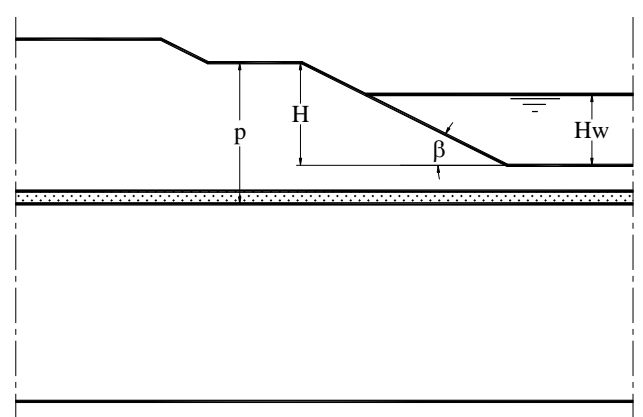

Fig. (11): Slope Geometry.

\section{ANALYSIS AND RESULTS}

Analysis of the parametric study results is presented hereinafter.

\subsection{Effect of Soil Cohesion}

There is no doubt that increasing the slope shear strength parameters will consequently increase the slope safety factor. The soil failure occurs when the shear stresses exceed their shear strength. So, the main factors which control the slope failure or stability are the soil shear strength parameters (c, . as increasing the soil strength leads to increased slope resistance against failure. Fig. (12) shows the relation between the soil cohesion (c) and the safety factor of the slope (F.S.) for different soil angles of internal friction. Increasing the soil cohesion resulted in a noticeable increase 
in the safety factor for the loaded slope in the presence of the slope stabilizing piles. The used soil internal angle of friction, although small, but the friction could be attained from the existence of sand traces, shells, and the dissipation of the pore water pressure due to using displacement piles. It is also noticed from the figure that soft clay soil with slope stabilizing system didn't reach the recommended value (1.50), but with added soil friction angle, the safety factors began to moderately increase. It should be noted that the water depth in the canal is equal (H-1.0) $\mathrm{m}$.

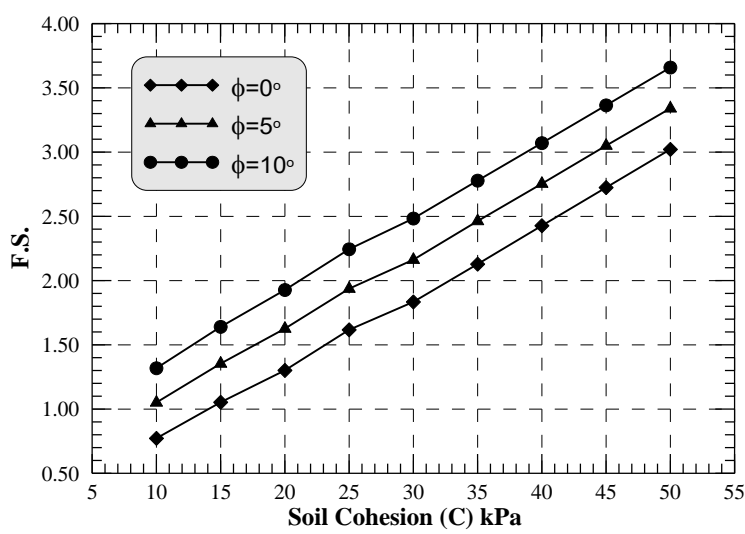

Fig. (12): Effect of Soil Cohesion on the F.S.

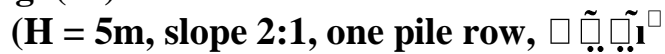

Fig. (13) represents the relation between the soil cohesion and the safety factors for different slope heights of $4.0,5.0,6.0 \mathrm{~m}$. For very soft cohesive soil with $\mathrm{c}=10 \mathrm{kPa}$, the slopes are unstable even with the existence of the stabilizing system, the presence of water in the canal, and for such small height. For higher cohesion values the safety factor increased.

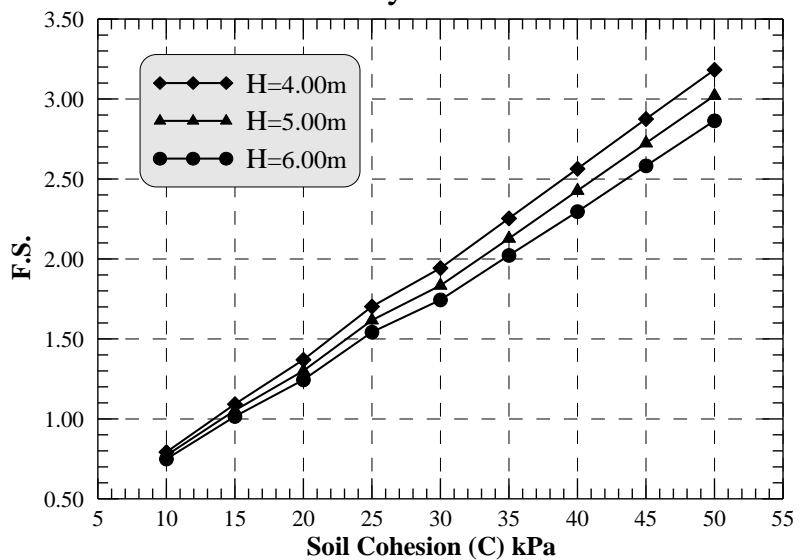

Fig. (13): Effect of Soil Cohesion on F.S. $(H=4.0,5.0$, and $6.0 \mathrm{~m}$, slope $2: 1$, one pile row, $\left.\mathbf{H}_{\mathrm{w}}=\mathbf{H}-1.0 \mathrm{~m}\right)$.

\subsection{Effect of Slope Height}

The relation between the slope height and the safety factor is inversely proportional, as increasing the slope height will decrease the safety factor, due to increasing the weight of the sliding mass. Fig. (14) shows the relation between the slope height and the slope safety factor for different cohesion values. Once again, for soft clays the safety factor didn't exceed 1.50 even with slopes with small height and with the existence of the stabilizing piles.

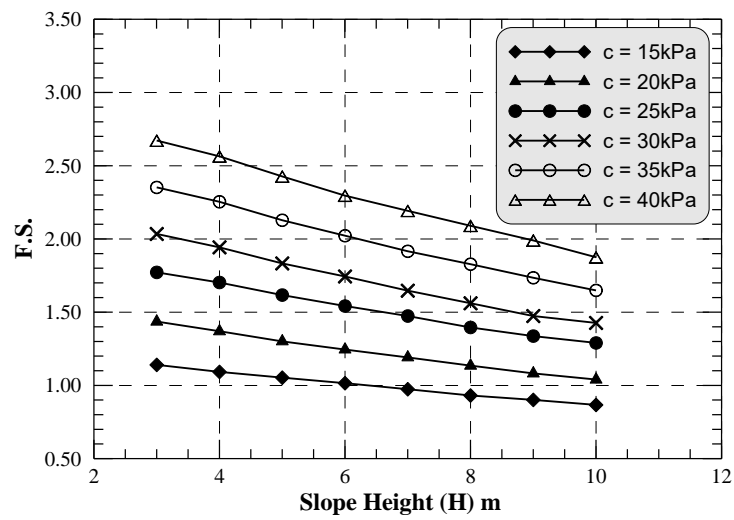

Fig. (14): Effect of Slope Height on F.S.

(slope 2:1, one pile row, $c=15,20,25,30$, $35,40 \mathrm{kPa})$.

\subsection{Effect of Slope Angle}

Fig. (15) shows the relation between the slope angle to the horizontal and the safety factor. Increasing the slope angle results in decreasing of the slope safety factor. It should be noted that the slope angle has a small effect on the slope safety factor; the slope remains stable even for steep slopes up to angle of $70^{\circ}$. This may be due to the cohesion between soil particles which makes the particles are well coherent together, which in turn needs higher driving forces to overcome the cohesion forces.

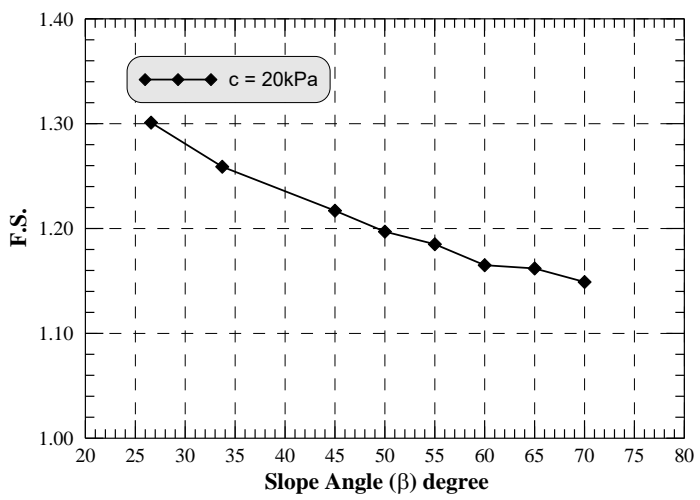

Fig. (15): Effect of Slope Angle on F.S. (H = $5 \mathrm{~m}$, one pile row, $\mathrm{c}=20 \mathrm{kPa}$ ).

\subsection{Effect of Depth of the Peat Layer}


Salem, Mashhour, Rashad

The existence of the peat layer controls the shape of the failure surface. The failure surface passes through the peat layer because it is the weakest layer in the whole slope's soil profile. Fig. (16) presents the relation between the depth of the peat layer and the slope safety factor for $\mathrm{c}=20.0$ and $35.0 \mathrm{kPa}$. Existence of the peat layer in the first meter of the slope resulted in minimum value of the slope safety factor as the failure occurred in the zone of the sloped loaded fill behind the piles row. The piles had almost no effect on the sliding mass. Increasing the depth of the peat layer within the slope resulted in reduction in the safety factor until the peat layer depth reached the slope toe. In all cases, failure took place due to the weight of the soil wedge, and the failure is planar in at the level in which the peat layer exists. The safety factor of the slope is almost constant when the peat layer is at or under the toe. This may be attributed to the formation of a passive soil block which resists occurrence of the failure surface through the peat layer in this case.

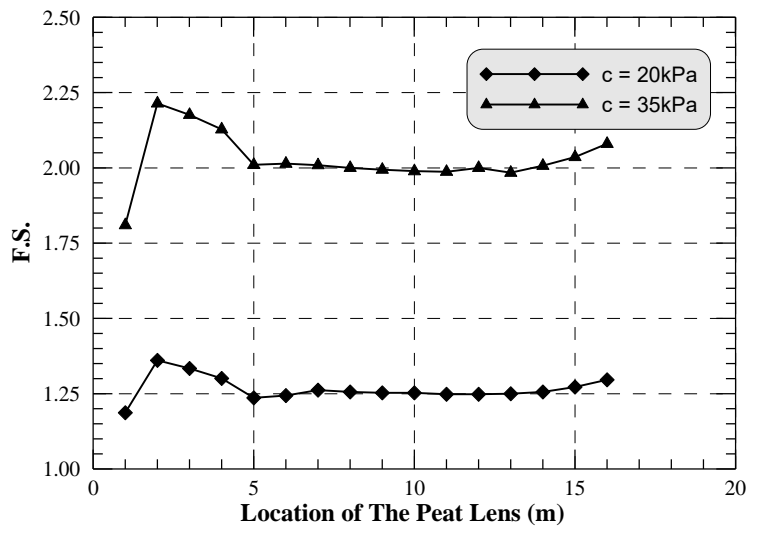

Fig. (16) Location of the Peat Layer versus F.S. $(H=5 \mathrm{~m}$, one pile row, $\mathrm{c}=20,35 \mathrm{kPa})$.

\subsection{Effect of Number of Pile Rows}

Fig. (17) shows the relation between the soil cohesion and the safety factor considering the effect of one row and two rows of stabilizing pile system. The location of the peat layer also defines the shape of the failure surface and the location of the stabilizing piles at the berm led to dividing the failure wedge into two. The figure shows that using a second row of slope stabilizing piles does not result in a noticeable increase in the safety factors, assuring that the gained increase in the safety factors are not proportional to the additional cost of using the second row. This may be directly related to the formation of a new failure surface in front and/or behind of the pile rows, either for the single or double rows, Fig. (18).

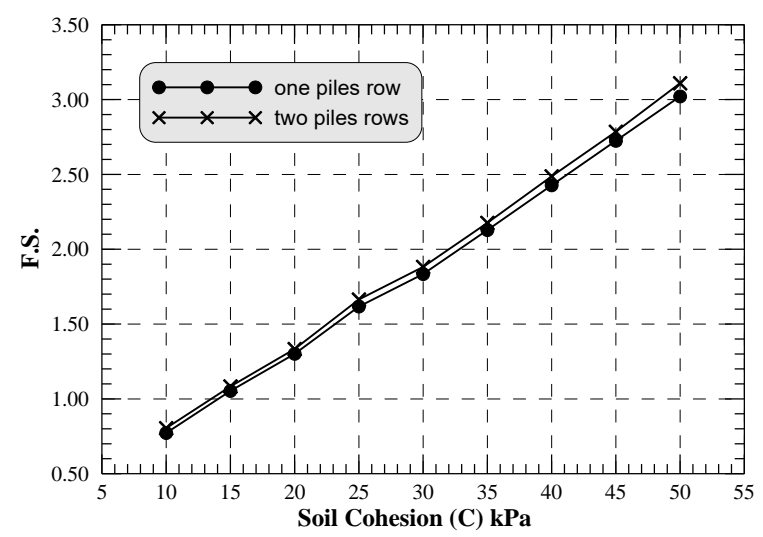

Fig. (17) soil cohesion versus F.S. $(H=5 \mathrm{~m}$,

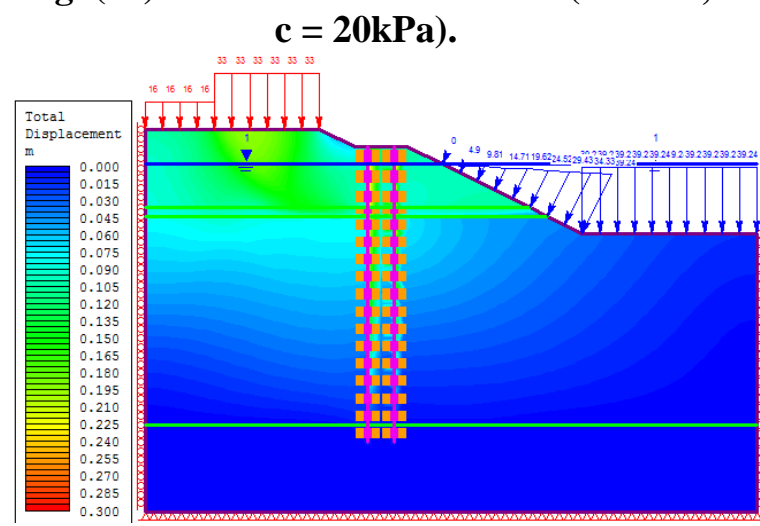

Fig. (18): Total Settlement Shading Contours of the Stabilized Slope under Equivalent Traffic Loads, $(\mathrm{H}=\mathbf{5 m}, \mathrm{c}=$ $20 \mathrm{kPa})$.

\subsection{Effect of Water Level in The Canal}

Fig. (19) presents the effect of the water level in the waterway along the embankment. The presence of water in the canal provides additional lateral resisting pressure subjected to the slope. This pressure equals $(\square \mathrm{z})$ where $\square$ is the water density and (z) is the selected water depth. The slope safety factor increased with the increase of the water depth in the canal. The most critical case is considered when the canal is empty and the soil is saturated. For soft soil with $\mathrm{c}=20 \mathrm{kpa}$, the embankment couldn't be safe when it was empty. So, additional methods must be used to stabilize the slope if any construction activities will require an empty canal. For a higher value of the soil cohesion, the slope safety factor reached 1.371 when the water way is empty. Although the safety factor didn't exceed 1.50 for a higher value of the 
soil cohesion, the slope will not fail provided that considering all the other construction conditions related to the project. At $\mathrm{c}=20$ $\mathrm{kPa}$, the slope safety factor will not reach the recommended value (1.50) even if the water depth in the canal reaches $4.0 \mathrm{~m}$. For a higher cohesion value at $\mathrm{c}=30 \mathrm{kPa}$ and to ensure that the slope safety factor will reach the recommended value (1.50), the water depth in the canal shouldn't be less than $2.0 \mathrm{~m}$.

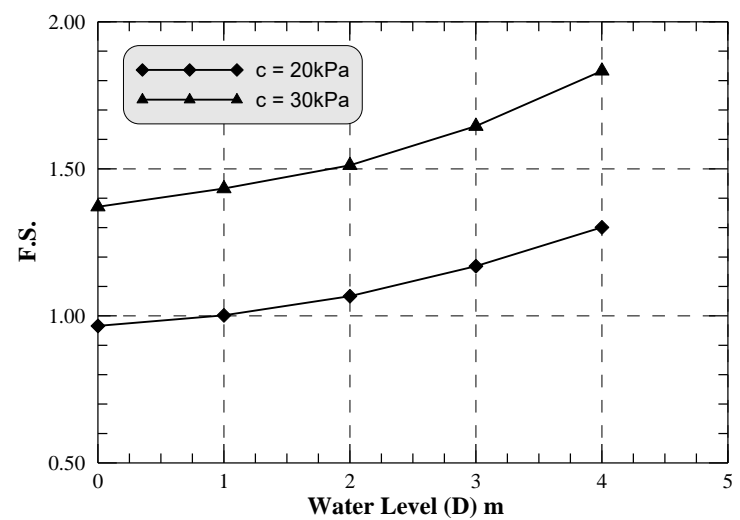

Fig. (19): Effect of Water Level on the F.S. $(\mathrm{H}=5 \mathrm{~m}, \mathrm{c}=20,30 \mathrm{kPa}$, one piles row).

\subsection{Effect of Presence of External Loads on The Slopes}

Loaded slopes are more susceptible to failure than unloaded ones due to a simple fact, loading the slope will increase the driving forces which the slope is subjected to. These external loads could be traffic loads, railways and buildings. Fig. (20) shows the relation between the soil cohesion and the slope safety factor in the presence and the absence of the design traffic loads for major highways, $33.0 \mathrm{kN} / \mathrm{m}^{2}$. The figure indicated that traffic loads could convert the stable slopes into unstable ones in the cases of soft clay. However, for medium stiff clays, the slope is still stable, but the safety factor is considerably reduced.

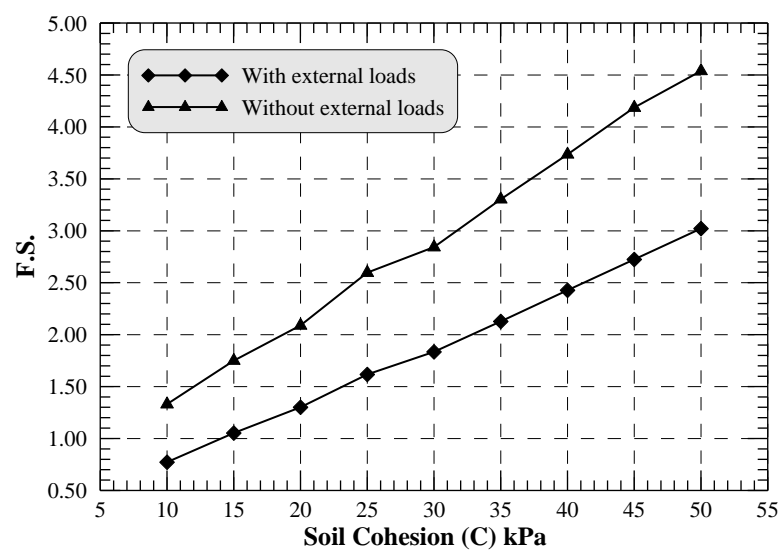

Fig. (20): Effect of Soil Cohesion on the

F.S. $(\mathrm{H}=5 \mathrm{~m}, \mathrm{c}=20 \mathrm{kPa}$, one piles row $)$.

\subsection{Effect of the Pile Properties}

The effect of the stabilizing piles properties on the slope such as pile diameters, stiffness, and the pile length on the slopes is also studied. For larger and smaller pile diameter, the slope safety factor seems to be unchanged, also changing the Young's modulus of the pile material which is reinforced concrete, the slope safety factor didn't change for higher or lower values for young's modulus. This may be attributed to that the piles used as a stabilizing system to support the slope which made of soft clay are much stiffer relative to the surrounding soil with more than 11000 times. By using piles with large diameter and high concrete quality with large values of Young's modulus, the slope safety factor is not affected and will reflect additional costs without any additional safety benefits. In order to check the effect of the pile length on stabilizing soft clay slopes, slopes supported by piles with different lengths were modeled and the relation is presented in Fig. (21). The piles lengths starting with $6.0 \mathrm{~m}$ up to $17.0 \mathrm{~m}$. Increasing the pile length $\mathrm{L}$ from $9.0 \mathrm{~m}$ up to $17.0 \mathrm{~m}$ is found to have nearly no effect on the slope safety factor as long as the end of the piles are embedded at least $1.0 \mathrm{~m}$ in the bottom dense sand layer. For lengths less than $9.0 \mathrm{~m}$, the slope safety factor begins to decrease till reaching 1.189 at $6.0 \mathrm{~m}$ pile length. Generally, the piles should be under the sliding surface with sufficient distance to avoid the mobilizing of the piles by the sliding mass through the stable soil. The sliding surface was defined by the existence of the peat layer; the piles resist the sliding mass by the lateral earth pressure, the 


\section{Salem, Mashhour, Rashad}

developed resisting pressure decreased with decreasing the pile length. At a certain depth which is $9.0 \mathrm{~m}$ in this case, the piles provided full resisting pressure against the driving mass, after that depth the piles no longer affect the slope safety factor. The slope safety factor decreased when the pile tip wasn't in the sand layer, this may be due to the fixity which was provided by driving the pile into the sand layer until refusal takes place. This fixity provides resistance against pile rotation.

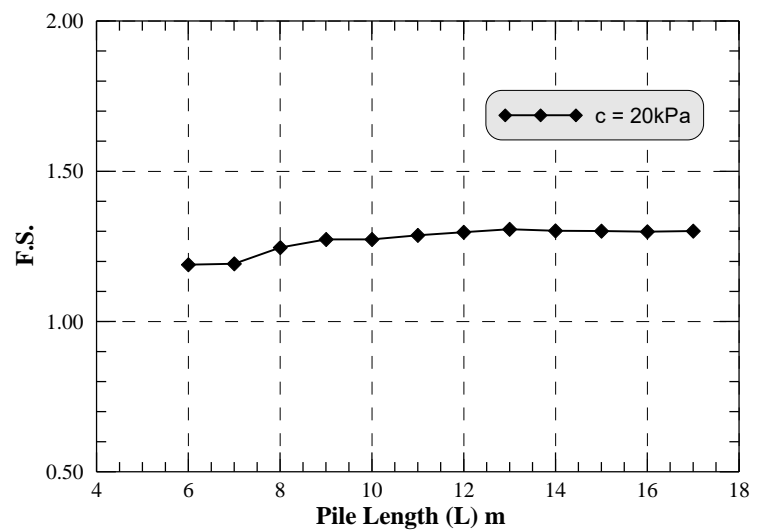

Fig. (21): Effect of Pile Length on the F.S. $(\mathrm{H}=5 \mathrm{~m}, \mathrm{c}=20 \mathrm{kPa}$, one piles row $)$.

\section{LIME/CEMENT COLUMNS}

From the previous results, stabilizing soft clayey slopes containing a peat layer with reinforced concrete piles seems to be ineffective in raising the slope safety factor to the recommended value of 1.50. The piles are very rigid elements with respect to the surrounding soil and zones of local failure could be formed behind or in front of the piles reducing the safety factors even after constructing the stabilizing system. For these reasons stabilizing slopes with chemical treatment such as using the lime/cement columns is proposed herein to stabilize the left embankment of the Al-Salam canal. This method is widely used in Finland, Sweden and Japan due to the existence of peat layers and soft soils in wide areas. The method depends on mixing the in-situ soil with lime and cement to stabilize the soft and organic soils. The lime/cement columns increase the soil shear strength with time. Just after the columns installation within a very short period of time ranges between 0.50-2.0 hours, the unslaked lime absorbs the ground water from the surrounding soil and water evaporation due to high temperature causing reduction in the soil water content. During this time ion exchange happens causing an increase in the plastic limit and decrease in the plasticity index rendering the soil stiffer consistency. After this time an action governed the increase in the soil shear strength called the pozzalnic reaction, in which the lime begins to react with the surrounding clay minerals forming higher strength crystals. This reaction affects the increase in the soil shear strength for long time periods ranging from 2.0 to 5.0 years, Broms, (2003).

The proposed stabilizing system consists of seven lime/cement columns installed by the dry method with $0.80 \mathrm{~m}$ diameter and length of about $16.0 \mathrm{~m}$ to reach the bottom sand layer which helps to dissipate the excess pore water pressure induced from the columns installation. The spacing between columns is $2.0 \mathrm{~m}$ placed in the active zone of the embankment as shown in Fig. (22). In the direction parallel to the waterway, the columns should be overlapped with a distance not less than $6 \mathrm{~cm}$ to ensure that the piles act as continuous wall which will increase the slope safety factor and reduce the lateral displacement.

The common lime/cement ratio used in the columns is 50/50. Holm et al., (1983a) have recommended that $75 \%$ lime and $25 \%$ cement should be used for long-term stabilization of soft clay and 50\% lime and 50\% cement for temporary stabilization. Laboratory tests with different lime/cement ratios are usually performed on the local soils to specify the most suitable ratio for the soil due to its consistency and natural water content.

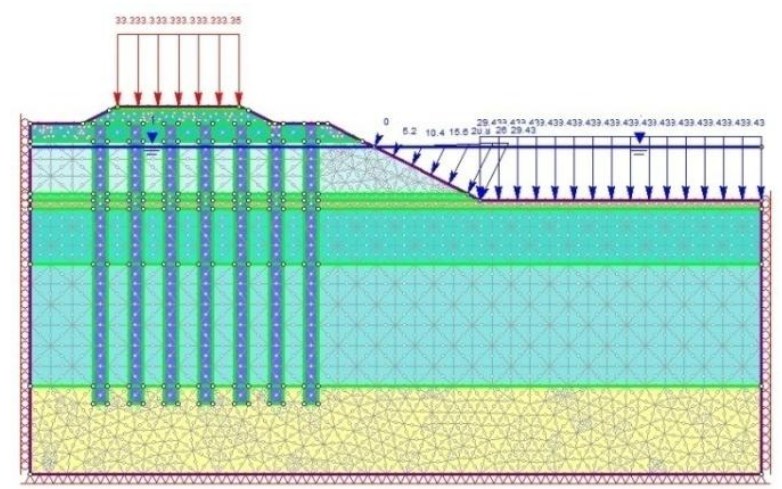

Fig. (22): Distribution of the Lime/Cement Columns.

The shear strength used in designing columns based on estimating the shear 
strength after 28 days after installation. The shear strength of lime columns is often underestimated since a large part of the longterm increase of the shear strength occurs after 28 days. The largest increase of the shear strength with lime/cement is expected for clays with a low sensitivity and water content between $40 \%$ and $80 \%$, Broms, (2003).To get the target effect of the lime/cement columns, the undrained shear strength of the stabilized soil should be less than 10 to $20 \mathrm{kPa}$, which is typical to the soil properties of the embankment. Assuming full interaction between the columns and the surrounding unstabilized soil, the undrained shear strength of the stabilized soil media is conservatively taken equal $100 \mathrm{kPa}$, with $10^{\circ}$ friction angle. The lime/cement unit weight is assumed to be $18 \mathrm{kN} / \mathrm{m}^{2}$. Carlsten and Ekstrom, (1995, 1997) reported that the ratio $E_{50} / c_{u, ~ c o l}$ could be assumed equal 200 for lime/cement columns, where $\mathrm{E}_{50}$ is the lime/cement modulus of elasticity at $\mathrm{q}_{\mathrm{u}} / 2, \mathrm{c}_{\mathrm{u}, \mathrm{col}}$ is the undrained shear strength of the columns and $q_{u}$ is the unconfined compressive strength. The Poisson's ratio used in modeling the lime/cement is equal to 0.45 to simulate the relatively large lateral expansion caused by lime during slaking, Broms, (2003).

Modeling the embankment with individual lime treated columns is considered an underestimation case as an average shear strength is normally used in the analysis assuming that the columns and the soft soil between the columns behave as a composite material, as reported in Broms (2003). The slope factor of safety using lime/cement columns was found to be higher than the safety factor from piles as a stabilizing system. The factor of safety is equal 1.913 which exceeded the recommended value 1.50, and even higher than the case of using two pile rows.

Fig. (23) shows the total displacement and the soil deformation of the embankment due to the external loads. It should be noted that the deformation is scaled up by a factor of 30 . The maximum calculated settlement under traffic loaded equal slope stabilized with piles is equal to $23.40 \mathrm{~cm}$, whereas this settlement value is reduced to $3.23 \mathrm{~cm}$ when lime/cement columns were used, as shown in Fig. (24).

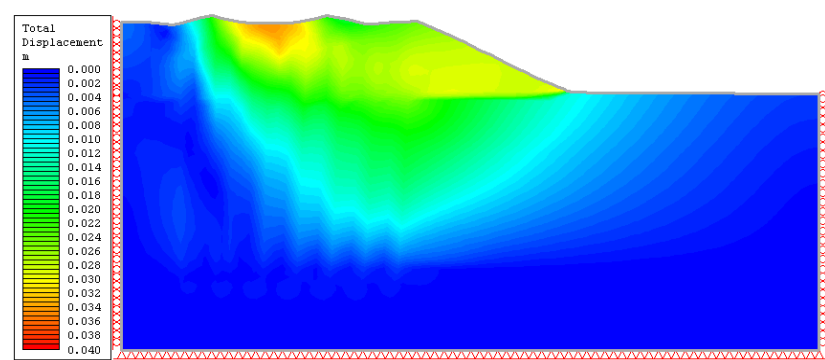

Fig. (23): Total Displacement and

Deformation of the Embankment (Deformations are scaled up by a factor of 30).

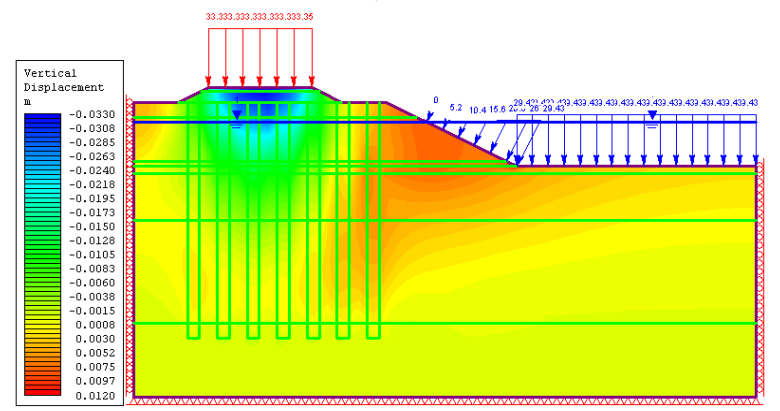

Fig. (24): Settlement of the Lime Treated Embankment.

Fig. (25) represents the lateral displacement of the embankment improved with lime/cement columns. The maximum horizontal displacement is found to be 2.86 $\mathrm{cm}$. The actual maximum horizontal displacement is expected to be larger than this value because the volume increased after columns mixing due to lime slaking. After few days from mixing the volume is then decreased, Broms (2003). On the other hand, the calculated maximum horizontal displacement of the embankment stabilized with piles is $14.30 \mathrm{~cm}$ in front of the piles, the soil displacements are considered relatively large because the piles as stabilizing system did not improve the surrounding soil shear strength in an effective way. Although the lime/cement columns take relatively long time to increase the soil shear strength, but it is an effective method to treat the soft clay and organic soil with very low costs compared to the reinforced concrete piles. In addition, the lime and cement are available and relatively cheap materials in Egypt. However, special industrial safety measures should be considered for the workers when installing lime/cement columns. 


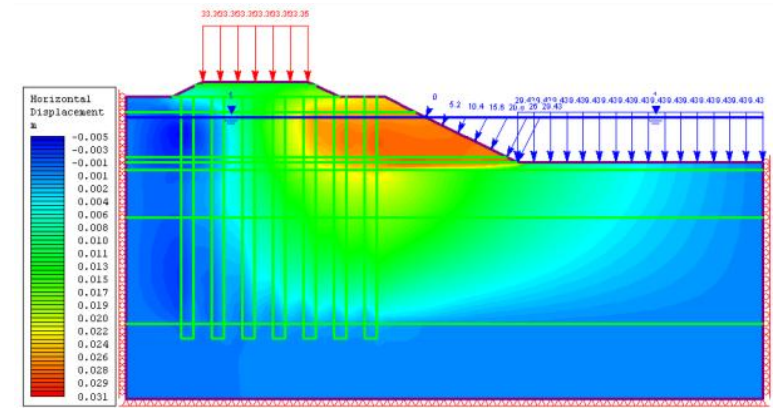

Fig. (25) the horizontal displacement of the embankment.

A critical case would arise when the rapid drawdown took place in the canal, and the slope is still saturated with water. In this case, the slope is found to be unsafe, because the water pressure on the slope shares in resisting the slope disturbing forces. To ensure that the slope is safe and reaches about 1.50 as a safety factor, the water level in the canal beside the embankment shouldn't be less than about $2.00 \mathrm{~m}$. The process of the slope widening will not require emptying the waterway. For constructing any projects in the future which could require emptying the canal, long-term analysis should be carried out on the soil and accordingly, a decision should be taken to choose other methods to stabilize the slope or to satisfy with the lime/cement columns as stabilizing system.

\section{CONCLUSION}

Based on the analysis made by the finite element program $\left(\mathrm{Phase}^{2}\right)$, the following conclusions could be obtained:

For the very soft and soft clay slopes, the piles are not effective as a stabilizing system.

Using two pile rows of stabilizing piles have not resulted in increasing the slope safety factor to the target value of 1.50 .

Increasing the soil cohesion and soil angle of internal friction, along with decreasing the slope height and slope angle resulted in an increase in the slope safety factor, with soil strength parameters showing greater effect than the slope height and slope angle.

Rapid drawdown of the water inside the waterway is not recommended to avoid slope failures as it was considered the most critical case when the canal is empty and the soil is saturated. However, if necessary it could be performed over a relatively long period of time to allow for the water level and saturation of the slopes to be reduced with time.

For soft clay containing organic layers, chemical soil treatment such as using lime/cement columns is considered an effective way to increase the slope safety factor and to increase the shear strength parameters in the failed region, but further parametric study and laboratory tests should be made in order to have a better view for stabilizing the soft soil with lime/cement columns and to determine the best lime/cement ratio and the different columns characteristics.

\section{REFRENCES}

[1] Al-Ashaal, A. A., Abdel-Motaleb, A.A., and Haggag, H. A., (1998), "Stabilizing embankment made of and founded over weak soil using piles: A case history", Soil Mechanics and Foundations, Journal of the Egyptian Geotechnical Society, Vol.9.

[2] Ausilio, E., Conte, E., and Dente G., (2001), "Stability analysis of slopes reinforced with piles". Computers and Geotechnics 28 (2001) 591-611.

[3] Bishop, A. W. (1966), "The strength of soils as engineering materials", Sixth Rankine Lecture, Geotechnique, 16(2), 89-130.

[4] Bransby, M. F. and Springman, S., (1996), "3-D Finite Element Modelling of Pile Groups Adjacent to Surcharge Loads". Computers and Geotechnics, Vol. 19, No.4, 301-324, 1996.

[5] Bransby, M. F. and Springman, S., (1999), "Selection of load-transfer functions for passive lateral loading of pile groups". Computers and Geotechnics 24 (1999) 155-184.

[6] Broms, B. B., (1964), "Lateral resistance of piles in cohesive soils". $\mathrm{J}$. Soil Mech. and Foundations Div. American Society of Civil Engrs 90, SM, 27-63.

[7] Broms, B. B., (2003), "Deep Soil Stabilization, Design and Construction of Lime and Lime/Cement Columns", Royal Institute of Technology Stockholm, Sweden.

[8] Cai, F., and Ugai, K., (2000), "Numerical Analysis of the stability of a slope reinforced with piles". Soils 
and foundations Vol. 40, No. 1, 73-84, Feb. 2000 Japanese Geotechnical Society.

[9] Carlsten, P. and Ekström, J., (1995 and 1997), Kalk- och kalkcement pelare -Vägledning for projektering, utforande och kontroll, "Lime and Lime Cement Columns - Guide for Project Planning, Construction and Inspection", Swedish Geotechnical Society, Report 4:95 and 4:95E, ISSN 1103-7237, Linkoping, Sweden, 103 and $111 \mathrm{pp}$.

[10] Chen, C. Y., Martin, G.R., (2002), "Soil-structure interaction for landslide stabilizing piles". Computers and Geotechnics 29 (2002) 363-386.

[11] Chow, Y.K., (1996), "Analysis of piles used for slope stabilization". International journal for numerical and analytical methods in geomechanics, Vol. 20, 635-646 (1996).

[12] Das, B. M., (1983), "Advanced Soil Mechanics", Washington: Hemisphere Pub. Corp.; New York: McGraw-Hill, c 1983.

[13] Egyptian Code of Practice for Soil Mechanics and Execution of Foundation (2001), $8^{\text {th }}$ Part (Stability of Slopes).

[14] Hassiotis, S., Chameau, J. L., and Gunaratne, M., (1997), "Design Method for Stabilization of Slopes with Piles". Journal of geotechnical and geoenviromental engineering, Vol. 123, No. 4, April 1997, P: 314-323.

[15] Holm, G., Tränk, R and Ekström, A., (1983a), "Improving Lime Column Strength with Gypsum", Proc. 8th European Conf. on Soil. Mech. a. Found. Engng., Helsinki, Finland, Vol. 2, pp 903-907.

[16] Hull, T.S., (1993), "Analysis of the stability of slopes with piles". Proc. $11^{\text {th }}$ Asian Geot. Conf., Singapore, 639-643.

[17] Ito, T., and Matsui, T., (1975), "Method to estimate lateral earth force acting on stabilizing piles", Soils and found. , 15, 43-59.

[18] Ito, T., and Matsui, T., (1978), "Do. Closure", soils and foundations, Vol.18, No. 2, PP. 41-44.

[19] Ito, T., and Matsui, T., Hong, W. P., (1981), "Design method for stabilizing piles against landslide (One row of piles)". Soils and foundations vol. 21, No. 1, Mar. 1981, Japanese society of soil mechanics and foundation engineering.

[20] Ito, T., and Matsui, T., Hong, W. P., (1981), "Extended Design Method for Multi-Row Stabilizing piles against landslide". Soils and foundations vol. 22, No. 1, Mar. 1981, Japanese society of soil mechanics and foundation engineering.

[21] Jeong, S., Kim, B., Won, J., and Lee.J., (2003), "Uncoupled analysis of stabilizing piles in weathered slopes". Computers and Geotechnics 30 (2003) 671-682.

[22] Lee, C.Y, Hull, T.S, and Poulos H.G., (1995), "Simplified pile - slope stability analysis". Computers and Geotechnics 17 (1995) P: 1 -16.

[23] Nian, T.K., Chen, G.Q., Luan, M.T., Yang, Q. and Zheng D.F., (2008), "Limit analysis of the stability of slopes reinforced with piles against landslide in non homogeneous and anisotropic soils".Can. Geotech. J. 45: 1092-1103 (2008).

[24] Poulos, H. G. and Davis, E. H., (1980), "Pile foundation analysis and design", New York: Wiley.

[25] Poulos, H.G., (1995), "Design of reinforcing piles to increase slope Stability". Can. Ceot. Jnl. 32: 808-81 8.

[26] Poulos, H. G., (1999), "Design of reinforcing piles to increase slope stability". Slope stability engineering, Yagi, Yamagami, Jiang 1999 Balkema, Rotterdam, ISBN 905809 0795.

[27] PHASE$^{2}, \quad$ Version 8.005, (2011), "Rocscience Inc.", Ontario, Canada.

[28] Randolph, M, F and Houlsby, G. T., (1984), "The limiting pressure on a circular pile loaded laterally in cohesive soil" Geotechnique 34, No. 4, 613-623.

[29] Reese, L. C., (1958), "Discussion on McClelland and Focht", Trans. Am. Soc. Civ. Engrs 123, 1071-1074.

[30] Rowe. R. K., and Poulos, H. G., (1979), "A method for predicting the effect of piles on slope behavior". Third International Conference on 
Salem, Mashhour, Rashad

Numerical Methods in Geomechanics / Aachen /2.6 April 1979.

[31] Viggiani, C., (1981), "Ultimate lateral load on piles used to stabilize Landslides". Proc. 10 ${ }^{\text {th }}$ In. Con. Soil Mechs. Foundn. Engs., Stockholm. Vol. 3: 555-560.

[32] Wei, W.B., and Cheng, Y.M., (2009), "Strength reduction analysis for slope reinforced with one row of piles". Computers and Geotechnics 36 (2009) 1176-1185.

[33] Won, J.,You, K., Jeong, S., and Kim, S., (2005), "Coupled effects in stability analysis of pile-slope systems". Computers and Geotechnics 32 (2005) 304-315.

[34] Youssef, A. M., and El-Gayar, M. S., (2000), "Technical Report of The loading Embankment Results made for the left embankment of El-Salam Canal from $\mathrm{km} 7.700$ to $\mathrm{km} \mathrm{7.750",}$ Faculty of Engineering, Al-Mansoura University. 